\title{
Peri-Urbanisation: Between Residential Preferences and Job Opportunities
}

\author{
Mohamed Hilal $^{1}$ (D) $\cdot$ Sophie Legras ${ }^{1} \cdot$ Jean Cavailhès $^{1}$
}

Received: 25 April 2016 / Accepted: 21 December 2016 / Published online: 11 January 2017

(C) Springer-Verlag Berlin Heidelberg 2017

\begin{abstract}
The debate on the nature and state of peri-urban development in Europe is dynamic. While residents and their residential preferences have long been identified as strong drivers of the process of peri-urbanisation, other influences have also been discussed, such as the supply side of the housing market or job opportunities for residents. This paper analyses the population and job growth trends in the last five decades of 230 urban areas in mainland France. The results show that the pattern of peri-urban development of all the large and medium cities of the country have strong common characteristics. In particular, the areas around cities have proven dynamic both in terms of population, as would be expected in the peri-urbanisation process described by the literature in France, but also in terms of jobs, which have been less analysed. A review of the economic literature on the determinants of firms' location choice puts forward some of the most relevant determinants that may explain a choice of location outside central cities. This helps put in perspective the role of job opportunities in shaping peri-urbanisation in France in the recent past.
\end{abstract}

Keywords Employment · France · Peri-urbanisation · Population · Urban areas · Urban growth

Dr. Mohamed Hilal

mohamed.hilal@inra.fr

Dr. Sophie Legras

sophie.legras@inra.fr

Jean Cavailhès

j.cavailhes@orange.fr

1 UMR1041 CESAER, Institut National de la Recherche Agronomique (Inra), AgroSup Dijon, Université Bourgogne-Franche-Comté, 26 bd Docteur-Petitjean, BP 87999, 21079 Dijon cedex, France

\section{Periurbanisierung: Zwischen Wohnpräferenzen und Arbeitschancen}

Zusammenfassung Die Debatte über das Wesen und den Zustand der Periurbaniserung in Europa ist dynamisch. Wohnpräferenzen wurden schon lange als wichtiger Treiber des Periurbaniserungsprozesses betrachtet. Auch andere Einflussfaktoren wurden diskutiert, z.B. die Angebotsseite des Wohnungsmarktes oder Arbeitsmöglichkeiten für Einwohner. Dieser Beitrag untersucht die Bevölkerungsund Beschäftigungsentwicklung der letzten 50 Jahre in 230 Stadtregionen auf dem französischen Festland. Die Ergebnisse zeigen, dass die periurbanen Entwicklungsmuster aller großen und mittleren Städte des Landes viele Ähnlichkeiten aufweisen. Das Umland der Städte hat sich besonders dynamisch entwickelt, nicht nur - wie zu erwarten - hinsichtlich der Bevölkerung, aber auch im Sinne von Arbeitsmöglichkeiten, die bisher weniger analysiert wurden. Eine Durchsicht der relevanten wirtschaftswissenschaftlichen Literatur deutet auf Determinanten der Standortentscheidungen von Unternehmen hin, die die Wahl eines Standorts außerhalb der Stadtkerne erklären könnten. Die Rolle, die Arbeitschancen bei der Periurbanisierung in Frankreich in den letzten Jahren gespielt haben, wird dadurch verdeutlicht.

Schlüsselwörter Beschäftigung · Frankreich · Periurbanisierung $\cdot$ Bevölkerung $\cdot$ Stadtregionen · Stadtwachstum

\section{Introduction}

During the $19^{\text {th }}$ and $20^{\text {th }}$ centuries, the growth and the concentration of population in developed countries were 
powered by industrialisation (Bairoch/Goertz 1986). The rapidly expanding industries in many large towns and cities drew people from the countryside, transforming landscapes and societies. Since 1950, urbanisation has slowed down and urban expansion has occurred in a scattered way around the periphery of cities. This fragmented pattern of growth in the urbanisation process is commonly termed "urban sprawl" in the English-speaking world (see Draper 1937 or Whyte 1958 for the first considerations of the matter, and Phelps/Wu 2011, among others, for a more recent analysis) and "peri-urbanisation" in continental Europe (Caruso 2001; Bontje/Burdack 2011; Nilsson/Pauleit/Bell et al. 2013). The peri-urban areas are characterised by poor centralised planning, leap frog development, continuous outward expansion, low density development, and a dominance of automobiles (Newman/Kenworthy 1989; Glaeser/ Kahn 2004; Nechyba/Walsh 2004; Burchfield/Overman/ Puga et al. 2006). Peri-urbanisation is not only driven by population growth but by changing lifestyles and consumption patterns: over the past 50 years in Europe, the urban areas have expanded on average by $78 \%$ whereas the population has grown by only 33\% (EEA 2006: 11). Nowadays, peri-urbanisation is the dominant urban form and affects towns and cities of any size, representing one of the hottest spatial planning challenges of the $21^{\text {st }}$ century (Antrop 2004; Cheshire/Magrini 2009; Hogan/Ojima 2012).

Many scholars have addressed at length the determinants of residential location choice (Alonso 1964; Mills 1967; Muth 1969), others have more recently pointed out some characteristics particularly relevant to peri-urbanisation (among others: Brueckner 2000; Cavailhès/Peeters/Sekeris et al. 2004; Glaeser/Kahn 2004; Nechyba/Walsh 2004). For the most part, the contemporary urban development process described above is explained by the gradual saturation of the central areas, improvements in accessibility, and increases in urban real estate prices, as well as by push factors (city nuisances) and pull factors (peripheral amenities). The high price of housing in the heart of the cities has prompted the least affluent households and families with children to leave the central districts to settle on the outskirts. Housing policies also explain the current spread. For example, in France the promotion of collective housing, from the 1950s, then of individual low-density housing, in the 1980s, led to expanding cities. In a first step the closest peripheral municipalities were included in the urban areas. In a second step, the nearby and distant rural areas became the "peri-urban fringe" (INSEE 2015: 16). The fall in transport costs, both public and private, also permits longer commutes and hence a residential location far from the workplace.

However, some of these determinants of residential location also apply to the location of productive activities. Indeed, for instance, increases in land prices and land scarcity also affect firms, and those least sensitive to agglomeration economies have increasingly preferred peripheral and accessible locations to develop their business. Indeed, the broadening of the economic base of the urban outskirts, in particular peri-urban areas, is increasingly discussed (see for instance Bontje/Burdack 2011 for a European perspective and on the specific French case Berger 2004; Paulus 2004; Halbert 2007; Berger/Aragau/Rougé 2014). How has the location of non-agricultural productive activities shaped the peri-urban space in France?

To address these questions, we analyse population and job growth trends in the last five decades in France by type of area (centres, suburbs and peri-urban belts of large and medium cities, Paris excluded ${ }^{1}$ ), and show that they have strong common characteristics. In particular, the peri-urban areas have proven dynamic both in terms of population and in terms of jobs. A review of the economic literature on the determinants of firms' location choice puts forward some of the most relevant determinants that may explain a choice of location at the urban fringe. This helps put in perspective the role of job opportunities in shaping peri-urbanisation in France in the recent past.

Section 2 provides some descriptive statistics on population and job growth in France by area type (central, suburban, peri-urban) since the late 1960s. Section 3 reviews determinants of the location choice of productive activities and, in light of this review, analyses peri-urbanisation trends in France between residential preferences and job opportunities. Section 4 provides a focus on the Toulouse region, which has experienced tremendous population growth and a booming economy in the last decades. Section 5 concludes that peri-urbanisation is not restricted to the location choice of people, but that it also concerns firms.

\section{Population and job growth trends in France}

France has some 66.3 million inhabitants, with 2.1 million in the five French overseas departments. It is the second most populated country in Western Europe, behind Germany (80.7 million) but ahead of the United Kingdom (64.7 million). France is one of the few countries where population growth results largely from natural increase. The average density is low (118 people per sq. $\mathrm{km}$ ) relative to its neighbours: 502 for the Netherlands, 373 for Belgium, 267 for the United Kingdom, 231 for Germany. The French population has enjoyed a long urbanisation phase since the mid- $19^{\text {th }}$ century. Compared to that in neighbouring coun-

\footnotetext{
${ }^{1}$ As explained below, we left out the case of Paris due to the peculiar demographic and economic size of this urban area (19\% of the French population), and also since it has already been extensively studied (see for instance Berger 2004; Gilli 2004 or Halbert 2007).
} 
Table 1 Division of population by area type in 2011 (mainland France)

\begin{tabular}{lllll}
\hline & $\begin{array}{l}\text { Urban areas of large cities } \\
\geq 50,000 \text { jobs } \\
(n=54)\end{array}$ & $\begin{array}{l}\text { Urban areas of medium } \\
\text { cities 10,000-50,000 jobs } \\
(n=176)\end{array}$ & Outside urban areas & Total \\
\hline Urban clusters - Central cities & $10,298,770$ & $5,032,823$ & - & $15,331,593$ \\
Urban clusters - Suburbs & $18,746,356$ & $2,761,784$ & $21,508,140$ \\
Nearby peri-urban & $5,841,518$ & $2,139,023$ & - & $7,980,541$ \\
Distant peri-urban & $4,244,579$ & $3,044,590$ & - & $7,289,169$ \\
Average and small areas & - & - & $4,617,752$ & $4,617,752$ \\
Other municipalities & - & - & $6,342,950$ & $6,342,950$ \\
Total & $39,131,223$ & $12,978,220$ & $10,960,702$ & $63,070,145$ \\
\hline
\end{tabular}

Source: 2011 population census (http://www.insee.fr/fr/information/2383184; January 6, 2017); authors' calculations

tries, French urban growth was initially moderate: cities were more populated than rural areas as early as 1850 in the United Kingdom, in 1910 in Germany and only in 1930 in France. Thereafter and during the post-war boom, urbanisation grew faster. Since 1936, the number of inhabitants of French urban units ${ }^{2}$ has more than doubled (from 22 to 48 million), while the rural areas have lost 6 million inhabitants (Hilal/Schaeffer/Détang-Dessendre 2013: 63).

Today, three quarters of the French population live in cities. The urban units with more than 5,000 inhabitants bring together $60 \%$ of the population (Hilal/Schaeffer/Détang-Dessendre 2013: 63). The most urbanised areas are the Paris and Lyon metropolitan areas, the Mediterranean coast, the old industrial areas of the North and the Northeast and the major traffic corridors, mainly the Rhône, Loire and Rhine valleys. Conversely, some regions have low population densities: mountain areas (Massif Central, Southern Alps, Corsica, Pyrenees), forest areas (e.g. Landes, Ardennes), agricultural areas (e.g. Champagne, inland Brittany, wooded pasturelands of Normandy).

The peri-urbanisation process appeared in the 1960s in Île-de-France (Bauer/Roux 1976) and accompanied the growth of towns and cities in most of the French regions in the 1970s, with a strong expansion and densification phase in the late 1970s and early 1980s. In the 1990s and thereafter, urban development spread on the outskirts of cities regardless of their size, with the pace of development differing from one region to another. Demographic dynamics were accompanied by very important commuting flows between the centre and the surrounding territories, and by land-use transformations with the construction of single detached houses with gardens in the peripheries (Bauer/

\footnotetext{
${ }^{2}$ In France, 'urban unit' is a municipality or a group of municipalities that includes a continuously built up zone (no break of more than 200 metres between two constructions) and at least 2,000 inhabitants. If the urban unit extends over several municipalities, the most populated municipality $(>50 \%)$ is the central city and the other adjacent municipalities are the suburb (INSEE 2015: 5).
}

Roux 1976; Le Jeannic 1997). By analysing employment and commuting patterns, the French National Institute of Statistics and Economic Studies (INSEE 2011) identified 792 functional spatial structures, called zonage en aires urbaines, corresponding to the daily urban system of cities. Each of these areas comprises a group of contiguous municipalities, without pockets of open land, encompassing a centre (urban unit) that provides at least 1,500 jobs, surrounded by rural districts or urban units (urban periphery) among which at least $40 \%$ of the employed resident population works in the centre or in the municipalities attracted by this centre. Depending on the number of jobs provided by the centre, INSEE (2011: $8 \mathrm{f}$.) distinguishes between "small areas" (from 1,500 to 5,000 jobs) and "average areas" (from 5,000 to 10,000 jobs). When the centre provides at least 10,000 jobs, the spatial structures are called "urban areas", with an "urban cluster", the central city and suburbs where employment is concentrated, and its surrounding "peri-urban area".

We separate these urban structures into two sets to analyse the population and the job growth trends of the "urban areas": those where the "urban cluster" provides at least 50,000 jobs (urban areas of large cities), and the others from 10,000 to 50,000 jobs (urban areas of medium-sized cities). The "peri-urban areas" are also divided in two sets according to the proximity of municipalities to the centre: the "nearby peri-urban" for road distances below median distance to the central city of the urban cluster, and the "distant peri-urban" for road distances above this. We combine the "distant peri-urban" areas with the "multicentric municipalities" of the urban areas, those where at least $40 \%$ of the employed resident population work in several urban areas (without this threshold being reached by just one of them); these two categories together then form a single block.

There are 230 urban areas in mainland France, inhabited by 52.1 million people $(83 \%)$. Table 1 reveals the following numbers: more than 39 million people live in the 54 urban areas of large cities, those with at least 50,000 jobs concentrated in the urban cluster. The population is dis- 
Table 2 Division of employment by area type in 2011 (mainland France)

\begin{tabular}{lllll}
\hline & $\begin{array}{l}\text { Urban areas of large cities } \\
\geq 50,000 \text { jobs }\end{array}$ & $\begin{array}{l}\text { Urban areas of medium } \\
\text { cities 10,000-50,000 jobs }\end{array}$ & Outside urban areas & Total \\
\hline Urban clusters - Central cities & $6,363,385$ & $2,968,352$ & $9,331,737$ \\
Urban clusters - Suburbs & $7,761,904$ & 933,247 & $8,695,151$ \\
Nearby peri-urban & $1,619,072$ & 471,861 & $2,090,933$ \\
Distant peri-urban & $1,009,405$ & 710,107 & $1,719,512$ \\
Average and small areas & & & $2,091,038$ & $2,091,038$ \\
Other municipalities & & & $1,823,140$ & $1,823,140$ \\
Total & $16,753,766$ & $5,083,567$ & $3,914,178$ & $25,751,511$ \\
\hline
\end{tabular}

Source: 2011 population census (http://www.insee.fr/fr/information/2383184; January 6, 2017); authors' calculations.

tributed over central cities (10.3 million), suburbs (18.7), nearby peri-urban (5.8) and distant peri-urban (4.2). The second-tier, urban areas of medium cities (176), has some 13 million inhabitants, distributed between central cities (5 million), suburbs (2.8), nearby (2.1) and distant (3) periurban areas.

Population change in these urban areas has involved three major steps since 1968 (see Figure 1). The suburbs of both large and medium centres grew until 1975, with an average annual growth of $4.67 \%$ for the seven years 1968-1975 in large cities ( $\geq 50,000$ jobs, cf. Figure 1a), and $3.31 \%$ in medium-sized cities $(<50,000$ jobs, cf. Figure $1 \mathrm{~b}$ ). This phase began after the Second World War with a large influx of new residents from rural areas, and from abroad too, to the large metropolises (e.g. Paris, Lyon, Marseille, Bordeaux, Toulouse, Nice) and then to all cities. Population growth $(+3.08 \%)$ has been equally strong, but slightly lower, in the nearby peri-urban areas of large cities ( $\geq 50,000$ jobs). After 1975 , in most cities peripheral areas showed the strongest growth in population change: the growth rate of the nearby peri-urban areas of large cities was $2.15 \%$ (cf. Figure 1a), and that of medium cities was

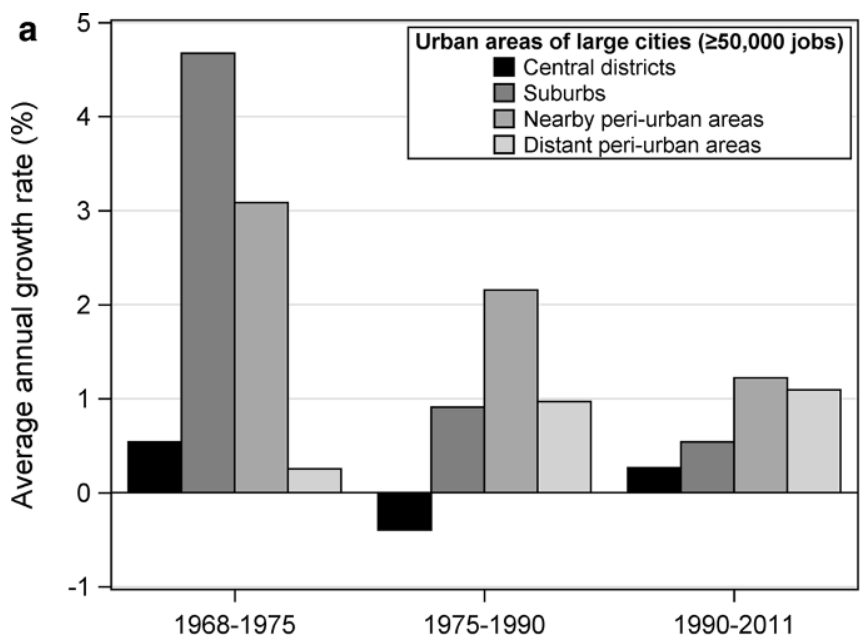

$1.60 \%$ (cf. Figure 1b). This resulted in the development of large densely populated areas on the outer fringes of the city in the nearby peri-urban areas (Baccaini/Sémécurbe 2009: 3 ). The residents of the periphery were typically employed in the main city, thus generating a large number of commuters who had to travel to and from the city on a daily basis (INSEE 2011). In contrast, in many central districts of cities the population growth slowed down $(-0.11 \%$ annually) or fell sharply $(-0.40 \%)$, while their suburbs were still characterised by relatively high annual growth $(+1.13 \%)$ (cf. Figure 1, time span 1975-1990). The annual growth rates of central districts, suburbs and surrounding areas tended to converge. Peri-urbanisation has continued in recent years (1990-2011) but at an annual rate below that recorded before $(+1.22 \%$ and $+0.89 \%$, respectively for large and medium cities) (cf. Figure 1, time-span 1990-2011, penultimate bars) except in the distant peri-urban areas where the annual rate is substantially higher $(+1.09 \%$ and $+0.79 \%$, respectively for large and medium cities) (cf. Figure 1, time span 1990-2011, last bars).

Employment concentration is more important than population concentration. In 2011, with more than 21.8 million

Figure 1 Population trends in French urban areas (a) Urban areas of large cities (b) Urban areas of medium cities Source: 1968, 1975, 1990 and 2011 population censuses (http://www.insee.fr/fr/information/2383184; January 6, 2017); authors' calculations 

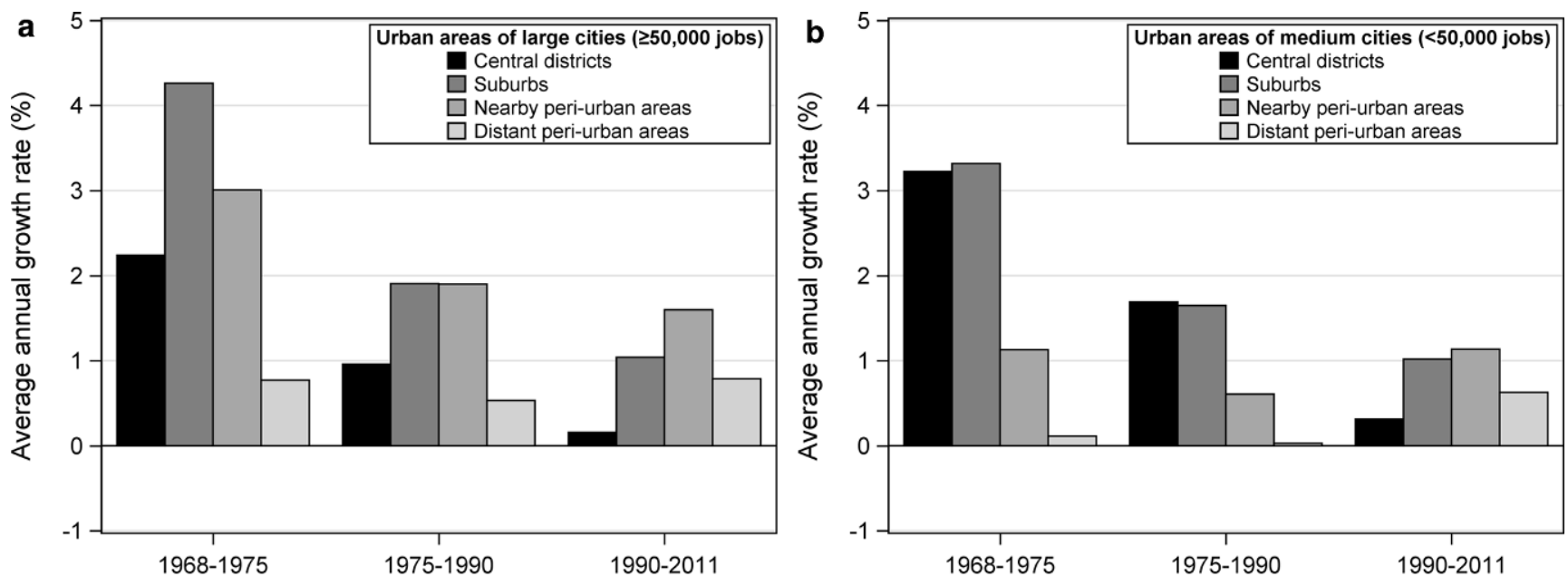

Figure 2 Employment trends in French urban areas (a) Urban areas of large cities (b) Urban areas of medium cities Source: 1968, 1975, 1990 and 2011 population censuses (http://www.insee.fr/fr/information/2383184; January 6, 2017); authors' calculations

employees, the 230 urban areas of mainland France account for more than $85 \%$ of employment (Table 2) compared to $83 \%$ of the population. The urban areas of large cities account for $65 \%$, and the number of employees is greater in the suburbs than in the central districts. The urban areas of medium-sized cities account for $20 \%$ of employment, with a pre-eminence of jobs in the central districts.

In the post-World War II period, France experienced fast economic expansion, like other developed countries. Jobs inside the large cities and in the peripheries increased substantially between 1968 and 1975. The suburb municipalities and the nearby peripheries saw the fastest employment gains, from $4.3 \%$ to $3.0 \%$ per year, all topping the $2.2 \%$ of the central cities and the $0.8 \%$ of the distant peripheries (cf. Figure 2a). The second set of urban areas (cf. Figure 2b) experienced consistent growth but below the first set, particularly in the suburbs $(+3.3 \%)$ and the nearby peripheries $(+1.1 \%)$. The central cities of this set had higher annual job growth $(+3.2 \%)$, above that of the large central cities. After 1975 and until 1990, jobs grew at a slower rate in both sets of urban areas. But the growth rates followed different patterns with a clear distinction between the urban areas of large and medium cities. In the first set, the employment growth rate of central cities amounted to a mere $1 \%$, but that of the suburbs and the nearby peri-urban areas, just below $2 \%$, remained important. In the second set, employment grew at approximately the same intensity as in the central cities $(+1.7 \%)$ and in the suburb municipalities $(+1.6 \%)$, but was slower in the nearby peri-urban areas $(+0.6 \%)$. After 1990 , the slowdown observed in employment growth became particularly relevant in the central cities of both sets. But employment has continued to grow in the suburbs and in both the nearby and distant peri-urban areas.

Consequently, peri-urban areas appear dynamic not only with respect to population, as would be expected, but also regarding employment. This poses the - still unresolved and highly debated - question of whether people follow jobs or jobs follow people, initially raised by Burns (1964). The causality link has been tested in the literature, following Carlino and Mills (1987), from different angles, such as the relevance of economic vs. quality of life factors in the decision to move (see Lowry 1966; Partridge 2010) or the timing of residential vs. job location decisions (such as in Deding/Filges/van Ommeren 2009). There appears to be mixed, context-dependent evidence (see the meta-analysis by Hoogstra/Florax/van Dijk 2005, for instance). With no intention to settle this debate, in the next section we analyse the determinants of firm location choice along the urban/ rural gradient.

\section{Firm location along the urban/rural gradient}

Economists have sought to explain the location decisions of productive units for over a century. Indeed, the uneven distribution of economic activity across space is a striking feature which has prompted a long intellectual tradition of interest in location choices in economics. Theoretical works on the location of production units, plants or firms, include early contributions by Weber (1909), Marshall (1920), Hotelling (1929) and Lösch (1940). "First nature" factors, of geographic character, distinguish footloose firms whose costs are insensitive to location from those that are linked to the existence of a natural or physical resource (such as ports, coal mines). However, "second nature" factors, relating to human actions and economic incentives, have been the focus of most of the more recent analyses. Following Krugman (1991a), the "new economic geography" literature has addressed location choice as resulting from a trade-off between opposing forces, those that pro- 
mote agglomeration (such as low transport costs, increasing returns to scale, a large and diversified workforce and the preference of consumers for variety) and those that lead to dispersion (such as market competition, high transport costs and immobile production factors or amenities) (Krugman 1991a; Krugman 1991b; Venables 1996; Fujita/Thisse 2002).

The economic rationale for economic clustering relates to agglomeration economies that induce firms to co-locate geographically. Various empirical studies find significant evidence of the existence of agglomeration economies, and they usually identify labour market pooling as the strongest mechanism (Rosenthal/Strange 2001; Dumais/Ellison/Glaeser 2002; Glaeser/Kerr 2009; JofreMonseny/Marín-López/Viladecans-Marsal 2011). A large labour market with differentiated qualification and skill levels is a driver of agglomeration economies, but too much competition for labour between firms may lead to high wages, leading firms to relocate to areas where they can offer lower wages (Krugman 1993). Competition on the market for goods drives product differentiation and monopolistic competition (Chamberlin 1933). Once again, labour needs and the trade-off between agglomeration (dis)economies and other costs differ dependent on the production sector. The characteristics of the area's economic activity are also important, since they have the ability to affect input sharing, knowledge spillovers, competition for labour and land, etc. Ellison, Glaeser and Kerr (2010), for instance, find a predominance of input sharing in their study of the drivers of agglomeration economies. Empirical studies also point to the importance of the spatial scale of analysis - knowledge spillovers appear relevant at a very local level (Jofre-Monseny/Marín-López/ViladecansMarsal 2011). Rosenthal and Strange (2008) also show that knowledge spillovers attenuate sharply with distance.

In order to explain the peripheral location of firms along the urban/rural gradient, it is useful to analyse the dispersion forces that may lead firms to locate in less dense areas. In this respect, Gaigné and Goffette-Nagot (2008) explain that these dispersion forces may arise from interaction on the goods market, labour market, and land market. Focusing on the case of rural industrialisation, they conclude that land rents and transport costs play a major role in explaining the location decisions of firms. Analyses of firm demography in France confirm that there is spatial differentiation in firm creation and closure between urban, peri-urban and rural areas (Huiban/Aubert/Dussol 2006; Huiban 2011). More generally, theoretical analyses put forward a canonical inverted U-shaped relationship between the spatial concentration of economic activity in a particular location and its degree of attraction for potential newcomers, following a dispersion/agglomeration/dispersion sequence that results from the trade-off between transport costs and economies of agglomeration (Krugman 1991a; Fujita/Thisse 2002).

In this section, we analyse some of the main determinants of firm location (transport costs, land prices and amenities) in the light of the recent trends in employment along the urban/rural gradient in France. We use data on specific sectors to illustrate the impact of these determinants, following the theoretical predictions discussed: the industrial sector, particularly sensitive to transport costs, the construction sector, sensitive to land prices, and "metropolitan functions" executives $^{3}$, sensitive to amenities. ${ }^{4}$ A fourth point is then developed on interactions between firms and households by way of the "in-place economy" sector. Note that in all the figures of this paper, Paris is not included in the "urban areas of large cities" category due to its peculiar economic characteristics (e.g. population, size, contribution to national gross domestic product, see footnote 1 ).

\subsection{Transport costs}

Transport is part of organisational strategy related to production, distribution and location (Vickerman 1980). Freight transport by road represented 288.7 billion tonskilometres in 2013 in France, $87.8 \%$ of the total national land-based freight transport (CGDD 2013: 106). Transport influences location decisions because it may affect competition on input and output markets, depending on the firm's sectorial activity. Indeed, if some activities, especially service-based ones, are very sensitive to the proximity of their consumer base, others such as industrial production are more sensitive to transport costs. In this respect, the existence and quality of transport infrastructure plays an important role, since it can change the balance between centripetal and centrifugal location factors (Fujita/ Krugman/Venables 1999). With high transport costs, markets are supplied by local firms and economic activity is dispersed. When transport costs fall, firms do not need to be so close to the input and output markets, and they can benefit from scale and agglomeration economies by clustering. They can also settle in more remote locations to get away from competition, and become more sensitive to the cost of other factor inputs. Leduc and Wilson (2012) and Redding and Turner (2015) provide recent surveys of the empirical literature on the link between transport costs and economic activity. Empirical studies on the effect of road infrastructure on plant location show that the existing level of infrastructure is relevant when assessing the significance

\footnotetext{
3 i.e.: executives involved in intellectual, managerial, and decisionmaking functions tied to intellectual services, design/research, business-to-business trade, management, culture, and leisure.

${ }^{4}$ Defined according to the typology of the Institut National de la Statistique et des études économiques (INSEE).
} 

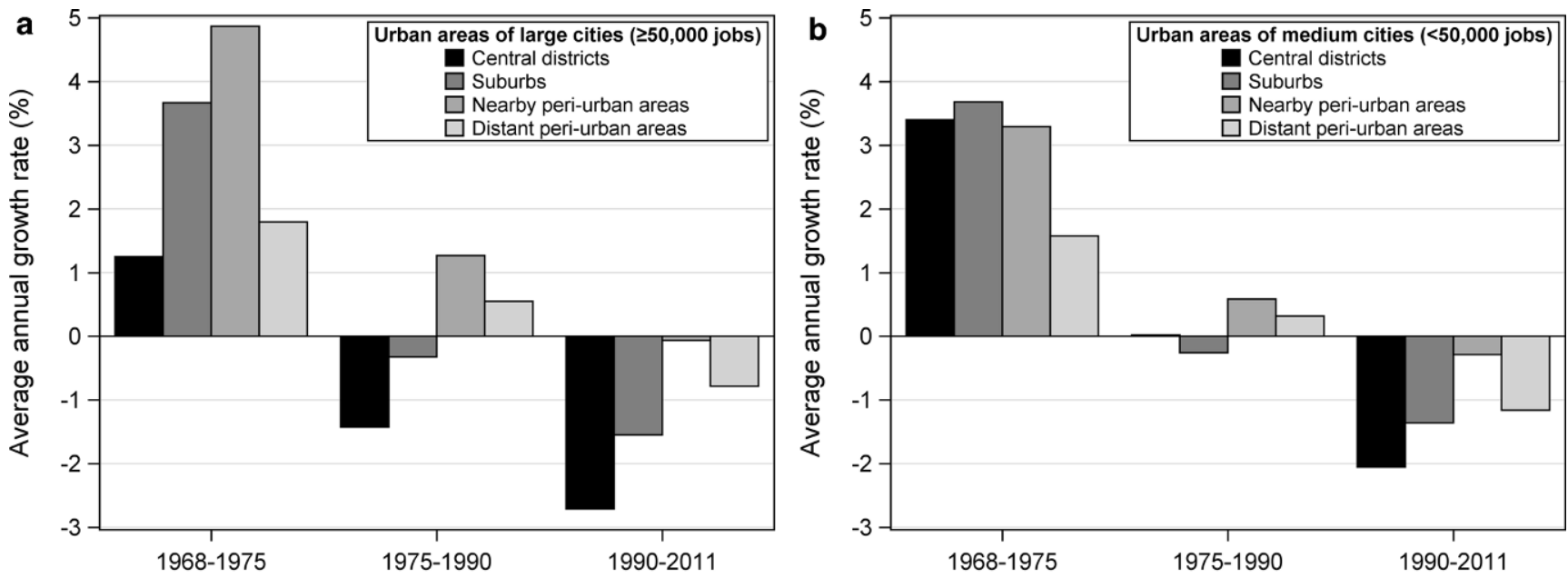

Figure 3 Industrial employment trends in French urban areas (a) Urban areas of large cities (b) Urban areas of medium cities Source: 1968, 1975, 1990 and 2011 population censuses (http://www.insee.fr/fr/information/2383184; January 6, 2017); authors' calculations

of the impact of investment in road infrastructure on firm location. More precisely, Guimarães, Rolfe and Woodward (1998), Guimarães, Figueiredo and Woodward (2000), and Holl (2004a) and Holl (2004b) report a significant impact of such investments on plant location in contexts where the motorway network has only recently been developed, constituting non-marginal increments (Holl 2012). In the US, where the road network is well developed, studies show that access to highways no longer constitutes an important determinant of location (Forkenbrock/Foster 1996), since there are no large regional differences. In the UK, Gibbons, Lyytikäinen, Overman et al. (2016) find substantial positive effects of new road infrastructure on employment and numbers of plants for small-scale geographical areas. However, within a region, firms tend to prefer to locate closer to slip roads (Kawamura 2001) and the interregional road network (Coughlin/Terza/Arromdee 1991; Smith/Florida 1994; Holl 2004a; Holl 2004b). This indicates an advantage of locating in peripheral locations such as peri-urban areas, where the road network is more modern and with, generally, easier access to highways. Hesse and Rodrigue (2004) show that suburban locations in interregional corridors are interesting from a logistics perspective, allowing local and long-distance transport flows to be connected. Empirical studies of the relocation of firms from central to peripheral locations confirm that proximity to interregional road infrastructure matters for relocating firms, especially in the manufacturing sector (Wasylenko 1980) and that these relocating firms have a greater tendency to settle near new infrastructure (Holl 2004c).

We illustrate the expected impact of transport costs on firm location in France through the evolution of employment growth rate per area type in the industrial sector, as shown in Figure 3. Although all areas show a sharp decrease in recent growth rates, the nearby peri-urban areas are the least negative in the urban areas of both large and medium cities (cf. Figure $3 \mathrm{a}$ and $3 \mathrm{~b}$ ). The industrial sector is supposedly the one that is the most sensitive to transport costs (as compared to the construction or tertiary sectors), hence the more prone to choosing a location that minimises these costs. With the expansion of cities, suburbs have become more congested and less directly connected to regional road infrastructures, while peri-urban areas have expanded with the construction of new roads such as rings and motorways (Lamure 1992; Hilal/Cavailhès/Détang-Dessendre et al. 2014; Fontes-Rousseau/Jean 2015).

\subsection{Land prices}

Land price is a determinant of the locations of both economic and residential activities. Land prices in dense areas tend to be high, but the potential demand for the firm's product may also be high. Relocation to a less densely populated area has the potential to reduce land costs, but it may also decrease the potential demand for the firm's products or reduce the benefits from agglomeration economies. Then, other things being equal, firms operate a trade-off between land cost and output demand or agglomeration economies, which results in different location choices depending on the characteristics of the firm. In particular, activities with land-extensive technology are assumed to have a stronger incentive to locate in areas where land is cheaper. The employment trend in the industrial sector depicted in Figure 3 illustrates this point. Firms from the service sector, that are less land-extensive, are more sensitive to demand factors and tend to locate in close proximity to households. Consequently, land prices also affect a firm's location decision in an indirect manner, through their effect on workers. Indeed, firms compensate high rent differentials by high wages: for instance Timothy and Wheaton (2001: 350) show that the 

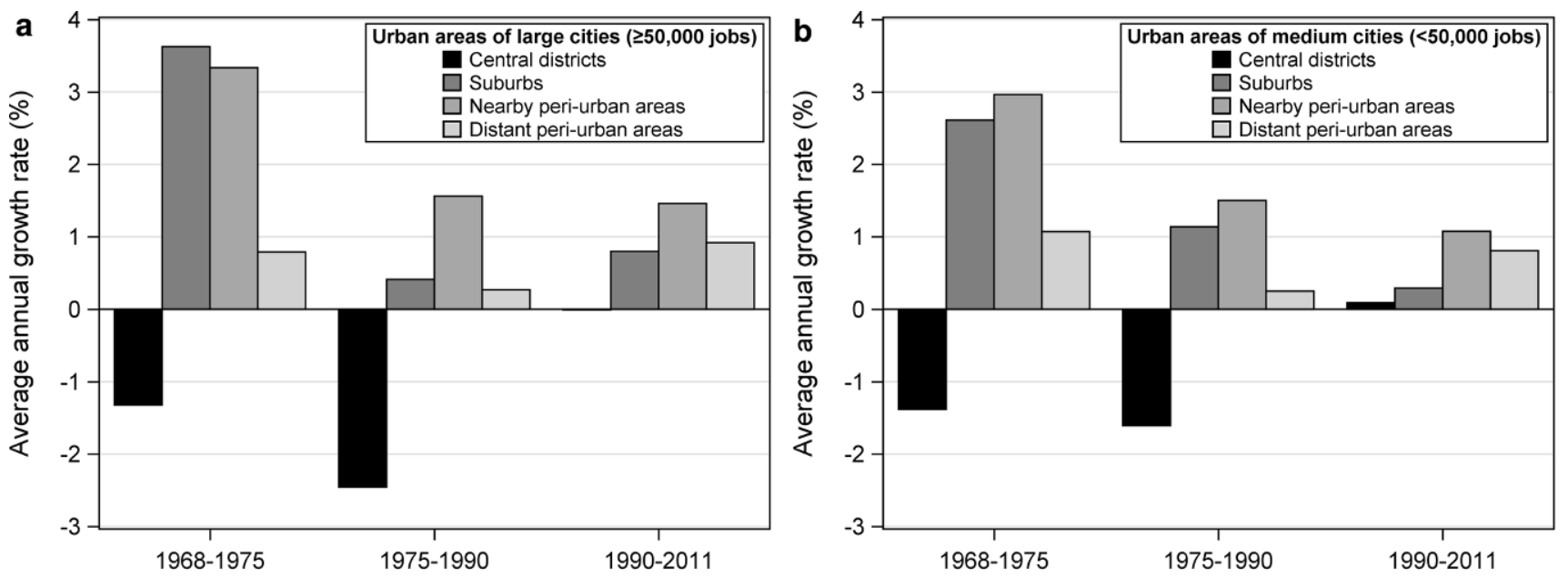

Figure 4 Construction employment trends in French urban areas (a) Urban areas of large cities (b) Urban areas of medium cities Source: 1968, 1975, 1990 and 2011 population censuses (http://www.insee.fr/fr/information/2383184; January 6, 2017); authors' calculations

wage differential between central and outlying business areas is $15 \%$ in Boston and $18 \%$ in Minneapolis. Peri-urban firms then offer households lower wages that are compensated by lower commuting costs and lower rents.

The land rent effect supposedly has the most impact on the construction sector, which needs easy access to the city centre, but less so to the regional road network. Figure 4 shows the evolution of employment annual growth rate in each area type in the construction sector in France. Indeed, the suburbs still experience positive growth rates despite a sharp decrease since 1970. Close and distant peri-urban areas are the most dynamic, due to low land rents but also because they are the areas where the demand for construction is highest. ${ }^{5}$

\subsection{Amenities}

Amenities can affect the location decisions of firms in an indirect manner (Kohler 1997). Residential amenities are the "place-specific goods or services that enter the utility functions of residents directly" (Gottlieb 1995: 1413). They allow for a wage disparity between areas: a firm established in a rich amenity area may reduce the wage paid to workers as compared to that paid in an area with a lower level of amenities. In a theoretical analysis, Kohler (1997) distinguishes between firms that follow their workers to high amenity areas, where they can offer lower wages, and firms that establish a trade-off between following and compensating for disamenities by higher wages. ${ }^{6}$ A large number of empiri-

\footnotetext{
5 See Pollard (2009) for an analysis of the evolution of the building sector and how it shaped the supply of single family homes in France and Spain.

${ }^{6}$ See Brueckner, Thisse and Zenou (1999) for an amenity-based theory of location by income.
}

cal studies analyse the link between amenities and local or regional development, jointly looking at the location decisions of households and firms (Knapp/Gravest 1989; Chen/ Rosenthal 2008; Kronenberg 2013). Results point to amenities playing a role in firms' location choices, particularly for information and communication technology firms (Gottlieb 1994; Gottlieb 1995). Indeed, in this case, firms are relatively footloose with respect to factors other than amenities, and employ a majority of highly qualified employees who tend to strongly value amenities. Other analyses of the US case include Beeson and Montgomery (1993) and Sivitanidou and Sivitanides (1995). In the case of France, Gilli (2004) discusses the example of Peugeot SA, who in 1991 decided to establish its automotive design network in Vélizy, located 15 kilometres south of Paris. This location is at the heart of the French automotive "golden triangle", where suppliers and other car manufacturers have increasingly settled, and within easy access of Paris, an airport and the national road network (Gilli 2004). However, the press releases specified that the new site also aimed to provide designers and engineers with serenity, a necessary condition to ensure inventiveness and creativity (Gilli 2004: 278). Indeed the site is located between the Meudon and Versailles forests, an area rich in amenities, assumed to be favourable to workers' productivity. Even if this example is set in the Parisian area, which we do not take into account in our calculations, it is a very well documented illustration of the mechanisms at work when amenities are approached as determinants of firms' locations. Some firms may be attracted to peri-urban areas that provide residential amenities that workers value (for instance, a pleasant landscape, see Cavailhès/Brossard/Foltête et al. 2009: 586 f.), and that allow them to reduce operational costs through lower rents and wages. 

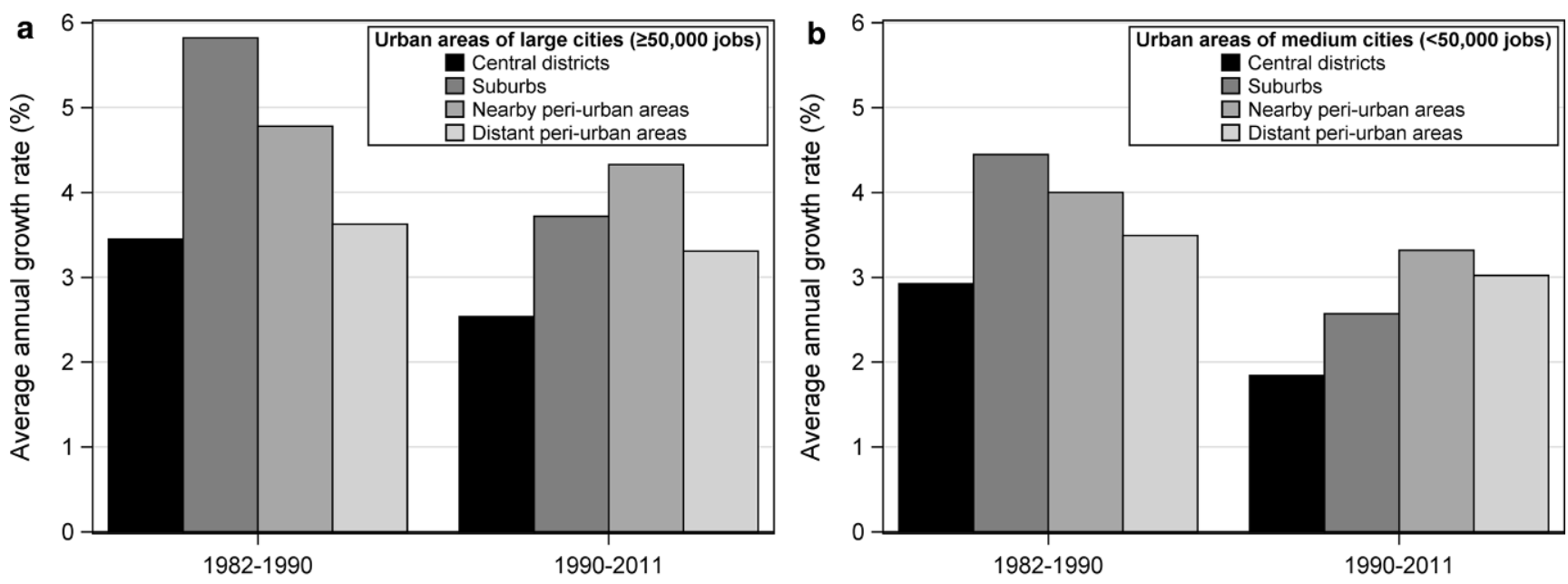

Figure 5 Employment trends of metropolitan functions executives in French urban areas (a) Urban areas of large cities (b) Urban areas of medium cities Source: 1982, 1990 and 2011 population censuses (http://www.insee.fr/fr/information/2383184; January 6, 2017); authors' calculations

Since the literature cited above points to the fact that highly qualified employees tend to be more sensitive to residential amenities, we focus on the case of metropolitan functions executives, that is those involved in intellectual, managerial, and decision-making functions tied to intellectual services, design/research, business-to-business trade, management, culture, and leisure. Figure 5 presents the recent trends in metropolitan functions executives for each area type in France. ${ }^{7}$ The average annual growth rate has been positive since 1982 in all areas covered by our analysis. The last period, covering 1990-2011, is characterised by a slight decrease in growth rate, which reaches the highest values in the close peri-urban areas of both large and medium cities. One should keep in mind that the relatively lower growth rates in central districts may be attributable to the fact that the stock of metropolitan functions jobs is mainly located in central districts.

\subsection{Interactions with households}

The analyses presented above show that peri-urban areas may prove attractive for firms for a range of factors related to their location, the location of their workers and that of their consumers. At this point, it is useful to reassert that some of these determinants may also apply to households, since for instance transport costs and land prices are at the core of the canonical monocentric model of residential location choice. Consequently, part of the job growth observed in peri-urban areas may be attributable to the in-place economy, which comprises activities implemented locally for the production of goods and services to satisfy the needs of people present in the area, whether resident or tourist.

\footnotetext{
${ }^{7}$ Data is only available since the census of 1982 , hence the difference in the temporal coverage regarding this type of employment.
}

Figure 6 presents the evolution of both in-place employment and that of activities outside the in-place economy. It shows that in-place employment has increased everywhere, especially outside central districts. At the same time, employment in the non in-place economy has decreased everywhere except in suburbs and nearby peri-urban areas, where it either increased (around large cities) or remained stable (around medium-sized cities). Consequently, both non inplace and in-place related employment play a more important role in job growth in the peripheries of cities than in central districts.

The tertiary sector is illustrative of one in which a large proportion of the jobs fall into the in-place category. Figure 7 presents the employment trend in the tertiary sector per area type in France. While the growth rates remain positive for all area types over the time-period, there is a clear offset towards suburbs and peri-urban areas after 1990, consistent with the demographic development there at this time. However, it is important to note that some of these tertiary jobs can also be qualified as "basics", in the sense of the economic base concept initiated by Sombart (for an explanation see Krumme 1968). This may explain their positive growth rate in areas that have lost population, such as the central districts.

In the next section, we focus on the southwest of France, home of the aerospace cluster, and in particular the case of Toulouse. Supported by local and national policies, Toulouse became one of the main industrial clusters of high technologies in France in the 1990s (Grosseti 2001). As we will see below, the whole urban area of Toulouse is characterised by high growth rates in employment, especially in metropolitan functions executive positions but also in the in-place economy. These trends also reverberate into the surrounding urban areas. 

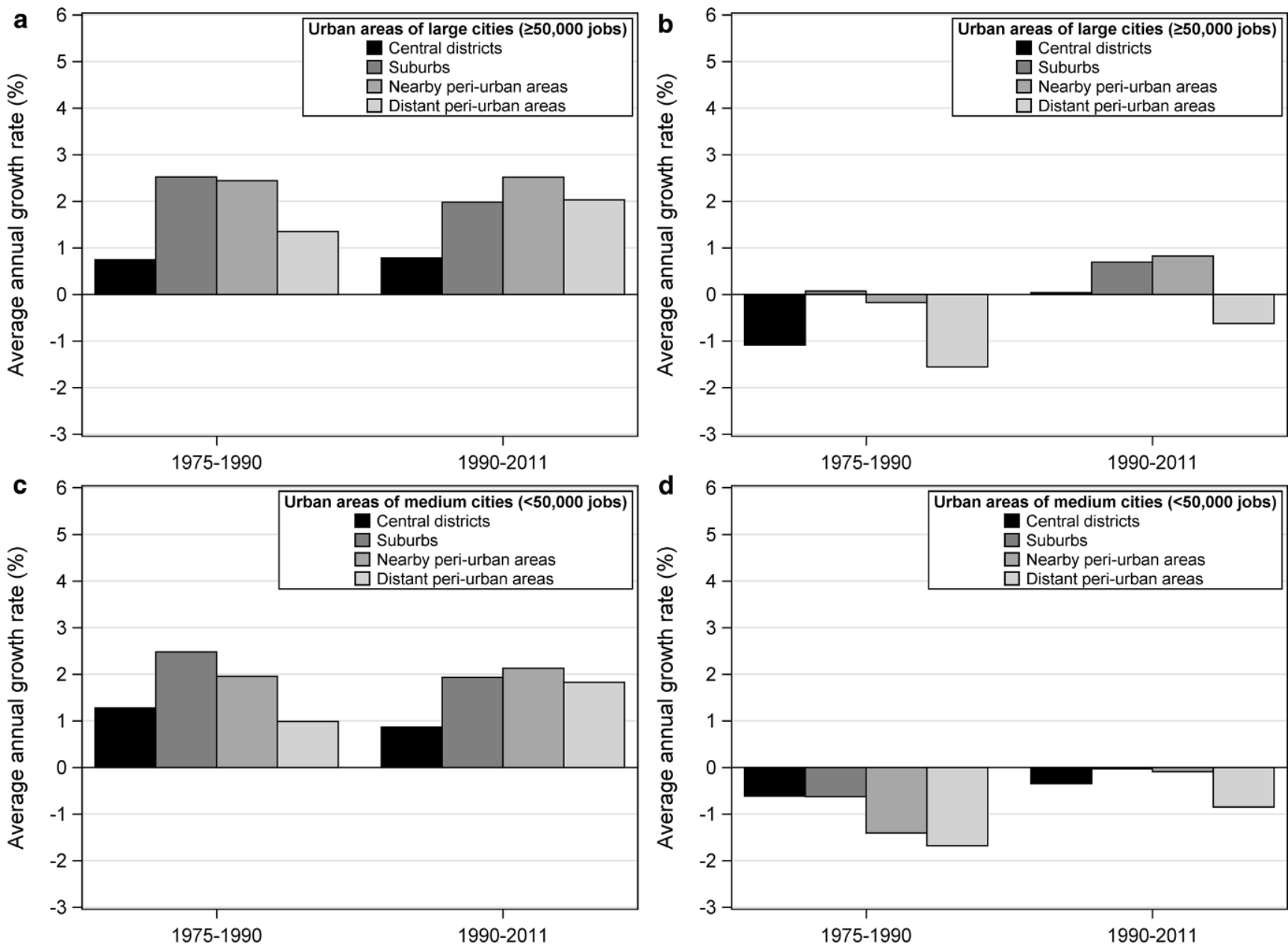

Figure 6 Trends of "in-place" and "productive" employment in French urban areas (a) In-place (b) Non in-place (c) In-place (d) Non in-place Source: 1975, 1990 and 2011 population censuses (http://www.insee.fr/fr/information/2383184; January 6, 2017); authors' calculations
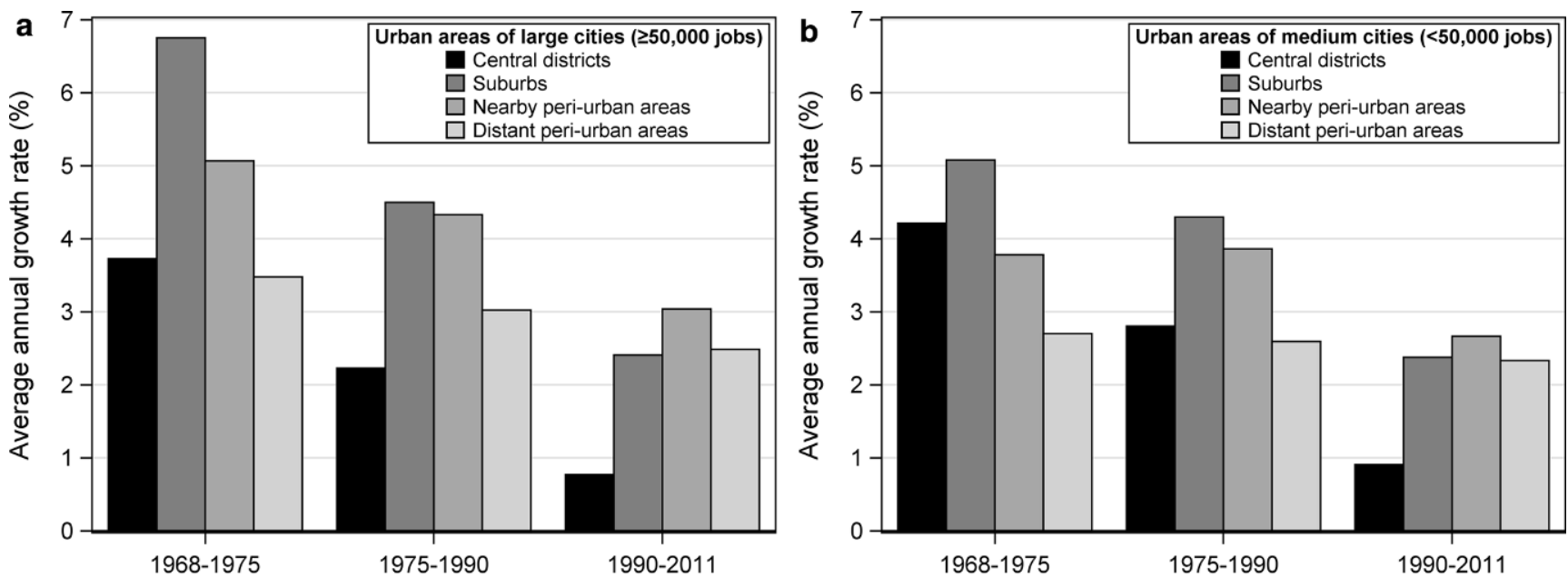

Figure 7 Tertiary employment trends in French urban areas (a) Urban areas of large cities (b) Urban areas of medium cities Source: 1968, 1975, 1990 and 2011 population censuses (http://www.insee.fr/fr/information/2383184; January 6, 2017); authors' calculations 


\section{Aerospace cluster and peri-urban dynamism: A focus on the Toulouse region}

The aerospace cluster, spanning between Bordeaux and Toulouse in the Aquitaine and Midi-Pyrénées regions is one of the most competitive internationally (Bawa/Etxebeste/ Konialian et al. 2013). The French Government catalysed its development in various ways, by establishing the headquarters of Airbus Industries, decentralising higher education services and sponsoring the Aerospace Valley Institution for Collaboration (Bawa/Etxebeste/Konialian et al. 2013). In 2005, the cluster received approval from the government policy of competitive clusters (pôles de compétitivité) and was designated as a "world class" cluster (Schönfeld/Jouaillec 2008: 2). The cluster gathers firms whose activities contribute to the construction of aircrafts and spacecrafts. In 2012, the 1,430 firms in the sector employed 123,571 workers, representing $13.8 \%$ of the employees of the non-agricultural market sector in the Region Midi-Pyrénées (91,138 workers), and $4.6 \%$ in the Region Aquitaine (32,433 workers) (Decret/Lupot/Ballet 2014: 2). The aerospace sector is industrial for $70 \%$ of its workforce, but its tertiary component is strong, with $30 \%$ of the workforce in IT services and specialised, scientific and technical activities (Decret/Lupot/Ballet 2014: 3). The employment areas of Toulouse, Bordeaux and Pau contain $83 \%$ of the workforce of the cluster, but outsourcing links are strong with firms spanned over the cluster in smaller cities (Ballet 2015; Cambon 2016). These outsourced firms benefit from locations with lower land and wage costs in the mediumsized cities, but need direct and frequent face-to-face links with the parent company to ensure just-in-time delivery and precise adaptation to technical needs (Marigot 2003; Kechidi/Talbot 2006).

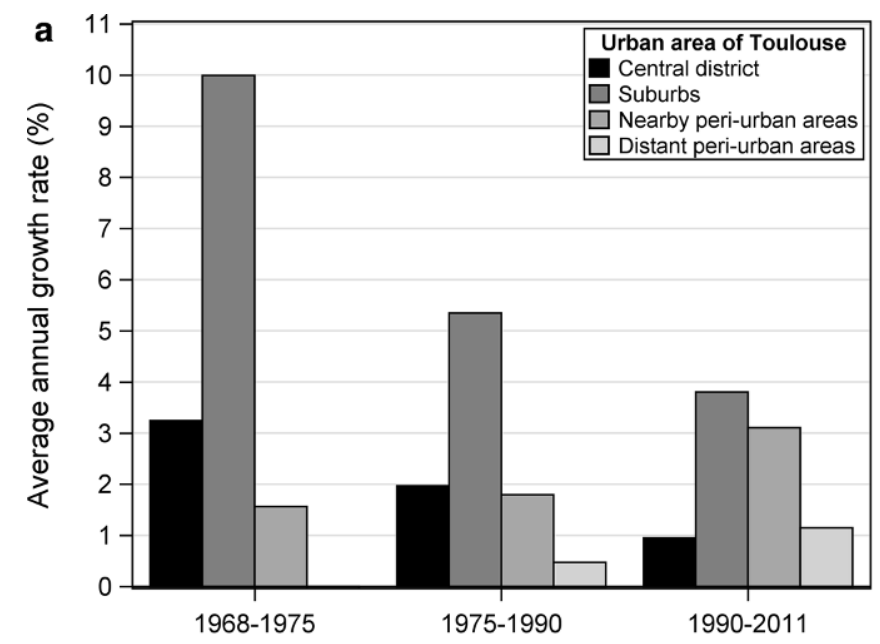

Figure 8 illustrates the dynamism of employment in the Toulouse urban area, compared to the national mean presented in Figure 2. Over the whole period since 1975, average annual growth rates have been substantially more than double the national figures for all area types except for the distant peri-urban areas at the beginning of the period.

This general dynamism of employment, as compared to the rest of France, especially during the last period of 19902011, in particular in suburbs and peri-urban areas (distant and nearby), applies to both in-place and non in-place activities, as shown in Figure 9 (and compared to Figure 6).

This applies to all area types, but especially outside the central city as shown by comparing Figures 6 and 9. This illustrates the important development of suburban and periurban areas around Toulouse in the last decades, attracting a high number of jobs related to proximity services in nearby municipalities. Furthermore, it appears that the dynamism of the in-place economy is not limited only to the Toulouse urban area. Indeed, satellite medium-sized urban areas surrounding Toulouse, such as Albi, Auch, Carcassonne, Castres, and Montauban, (see Figures 8 and 9 for average growth rates) are also characterised by high positive growth rates of employment in these sectors, again especially in areas outside the central city. With Auch, Carcasonne, Castres and Montauban, Albi forms part of a polycentric urban system, centred in Toulouse and comprising medium-sized cities located less than one-hour drive away. They appear to be positively impacted by the dynamism of employment in Toulouse, and this directly affects the economic profile of their peri-urban areas, as illustrated by the average annual growth rates of employment presented in Figure 10.

Also, these peripheral areas host numerous firms that provide metropolitan functions executive jobs, attracted to locations outside the city centre for the reasons developed in

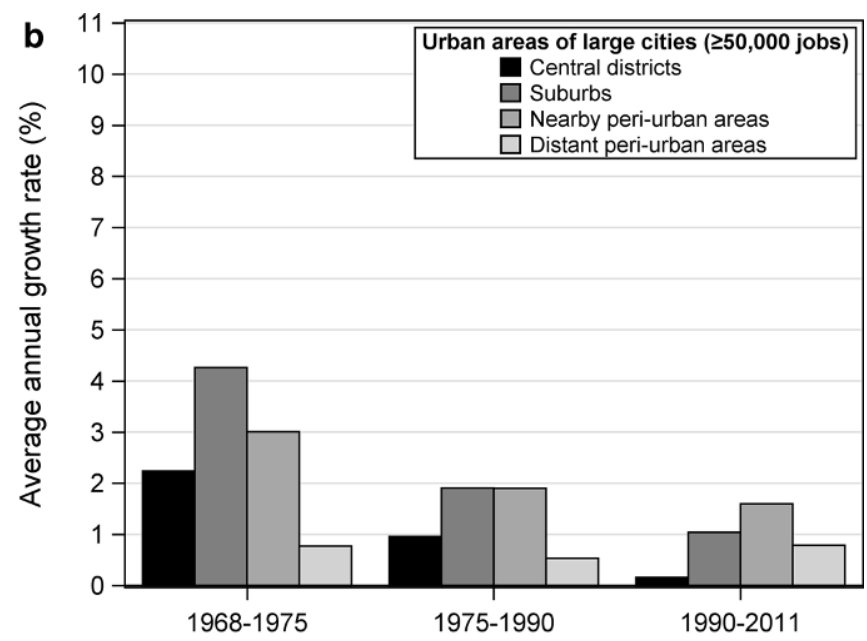

Figure 8 Employment trends in Toulouse and France (a) Toulouse (b) Urban areas of large cities Source: 1968, 1975, 1990 and 2011 population censuses (http://www.insee.fr/fr/information/2383184; January 6, 2017); authors' calculations 

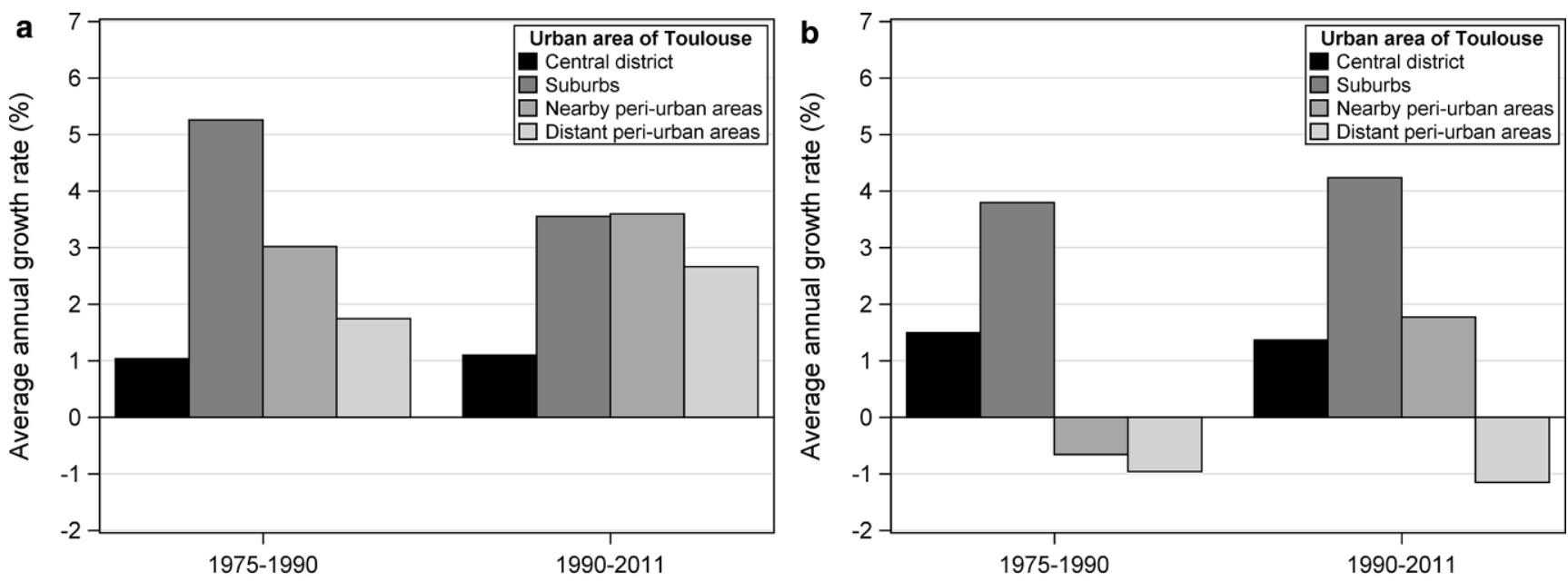

Figure 9 Employment trends in the in-place and productive sectors in Toulouse (a) In-place (b) Non in-place Source: 1975 , 1990 and 2011 population censuses (http://www.insee.fr/fr/information/2383184; January 6, 2017); authors' calculations
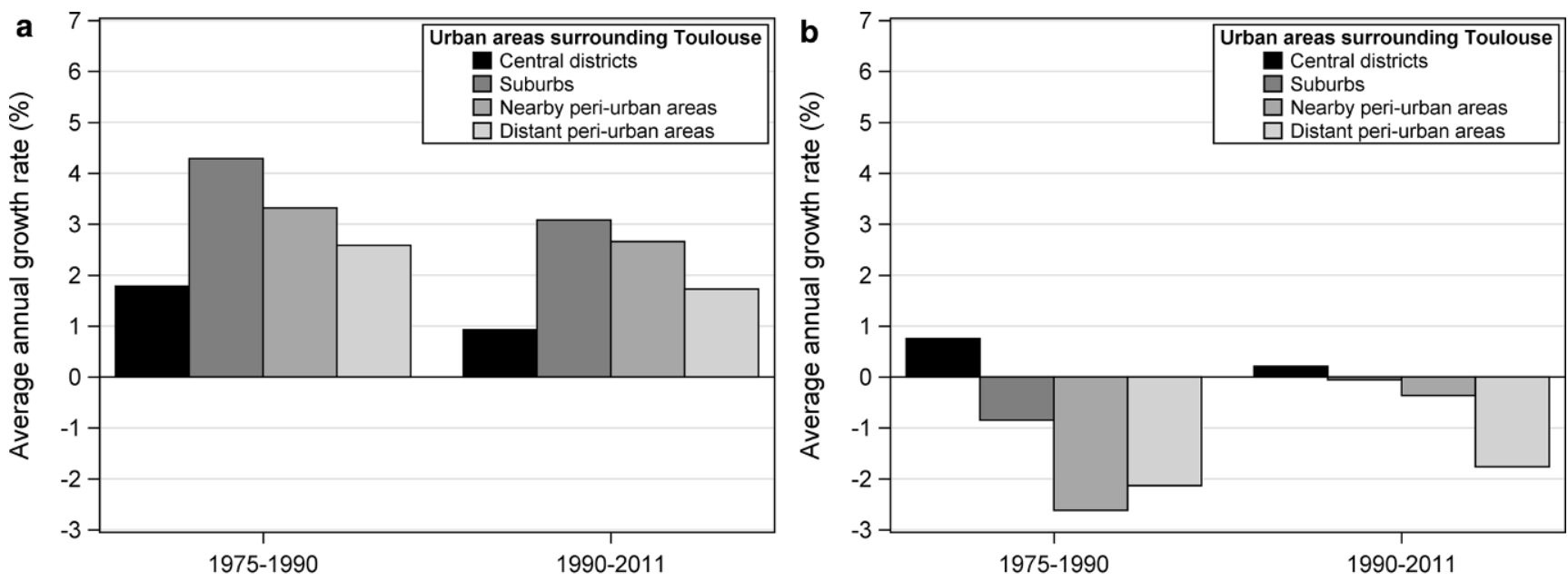

Figure 10 Employment trends in and outside the in-place economy in urban areas surrounding Toulouse (a) In-place (b) Non in-place Source: 1975, 1990 and 2011 population censuses (http://www.insee.fr/fr/information/2383184; January 6, 2017); authors' calculations

the previous section. Figure 11 illustrates this point. Indeed, the Toulouse urban area is ranked third in France regarding its share of employment in metropolitan functions executive jobs, after Paris and Grenoble.

\section{Conclusion}

Peri-urbanisation, seen as population growth around the periphery of cities, is a major spatial trend of recent demographic developments, in particular in Europe. The European Environment Agency (EEA) identifies "the means of transportation, the price of land, individual housing preferences, demographic trends, cultural traditions and constraints, the attractiveness of existing urban areas, and, not least, the application of land use planning policies at both local and regional scales" (EEA 2006: 6) as the set of forces contributing to the decision "to realise new lifestyles in suburban environments, [...] to live increasingly farther away from city centres [...]" (EEA 2006: 7). As we have shown in this paper, peri-urbanisation is not restricted to the location choice of people, but also concerns firms. In the US, the peri-urbanisation of jobs at an important scale dates back to the 1950s; since then job density has continuously decreased in central cities ${ }^{8}$ while the suburbs have gained jobs. In particular between 1990 and 2000, the number of jobs increased annually by $1.4 \%$ in the suburbs and decreased by $0.1 \%$ in central cities (Gobillon/Selod/Zenou 2007: 2404). There is no reason to believe that other European countries did not experience a trend comparable to that seen in France or the US.

\footnotetext{
${ }^{8}$ From $70 \%$ of Metropolitan Statistical Areas jobs in 1950, to $57 \%$ in
} 1980 and 47\% in 2000 (Gobillon/Selod/Zenou 2007: 2403). 

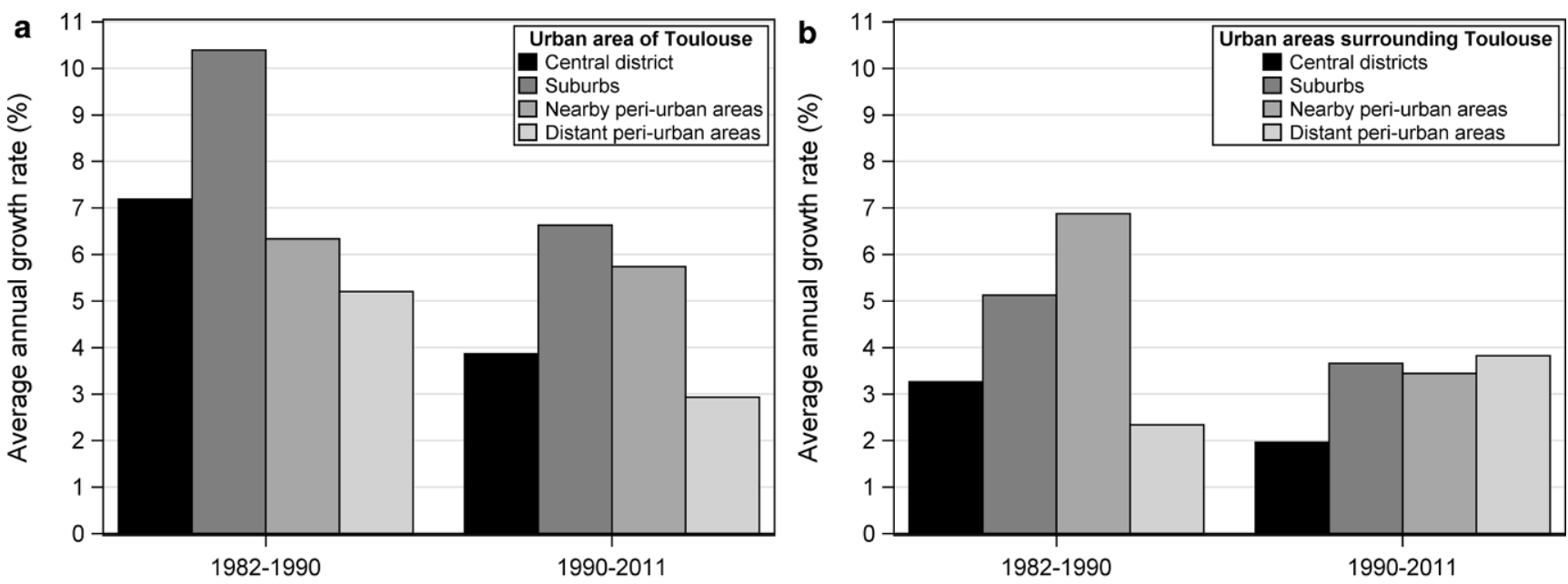

Figure 11 Employment trends of metropolitan functions executives in Toulouse and in the surrounding cities (a) Toulouse (b) Surrounding cities Source: 1982, 1990 and 2011 population censuses (http://www.insee.fr/fr/information/2383184; January 6, 2017); authors' calculations

A comparative analysis of the peri-urbanisation of jobs and residents is important due to its potential consequences such as spatial mismatch, a natural extension to this present paper. Since the seminal paper by Kain (1968), numerous analyses have been devoted to this question, especially in the US where jobs have followed a peri-urbanisation trend, while poor households have remained in the city centres. In France, poor households, especially the unemployed, are over-represented in city centres (Floch 2014) while the growth rate of jobs is lower in city centres than in the suburbs or peri-urban areas (Lainé 2000; Beaucire/Chalonge 2011). Analyses of the spatial aspects of unemployment have dealt with the impact of public policies in favour of poor neighbourhoods (Zenou 2004), but to the best of our knowledge there has been no investigation into the spatial mismatch along the rural/urban gradient. Another line of research has addressed the effect of job decentralisation on commuting time, with ambiguous results. ${ }^{9}$ This question is linked to the previous one, since spatial mismatch depends on commuting time. It is also linked to the environmental impacts of peri-urbanisation, due to the important contribution of the transport sector to the emissions of greenhouse gases and local pollutants. This opens the way for research

\footnotetext{
9 See Crane and Chatman (2002: 11) who show that employment peri-urbanisation reduces commuting time, with strong differences by industry: "Construction and wholesale employment dispersal are associated with shorter commutes, while manufacturing and government employment dispersal with longer commutes. Retail and service employment does not appear to be strongly associated with commute length". See also Weitz andCrawford (2012: 53) who show that "of 358 metropolitan regions, $227(63 \%)$ experienced job gain and a decrease in job accessibility, confirming the stereotypical pattern of job sprawl in growing regions". Finally, Hu (2014: 675) shows that in the Chicago metropolitan area from 1990 to 2010 "spatial changes have increased job accessibility for the poor while socioeconomic transformation has adversely affected it".
}

on these topics, both in France and in other European countries.

\section{References}

Alonso, W. (1964): Location and land use. Cambridge.

Antrop, M. (2004): Landscape change and the urbanization process in Europe. In: Landscape and Urban Planning 67, 1-4, 9-26.

Baccaini, B.; Sémécurbe, F. (2009): La croissance périurbaine depuis 45 ans. Extension et densification. Paris. = INSEE Première 1240.

Bairoch, P.; Goertz, G. (1986): Factors of Urbanisation in the Nineteenth Century Developed Countries. In: Urban Studies 23, 4, 285-305.

Ballet, B. (2015). La filière aéronautique et spatiale en Aquitaine et Midi-Pyrénées en 2014. Un salarié sur dix des secteurs marchands du grand Sud-Ouest. Paris. = INSEE Flash 26.

Bauer, G.; Roux, J.-M. (1976): La Rurbanisation ou la ville éparpillée. Paris.

Bawa, J.; Etxebeste, I.C.; Konialian, M.; Martin, J.N.R.; Ruiz-Taboada, H. (2013): Aerospace Cluster in the Toulouse Region. Boston, MA.

Beaucire, F.; Chalonge, L. (2011): Evolution de l'emploi dans les couronnes périurbaines (1982-2007): de la dépendance à l'interdépendance. In: Pumain, D.; Mattei, M.-F. (eds.): Données urbaines 6. Paris, 61-64.

Beeson, P.; Montgomery, E.B. (1993): The effects of colleges and universities on local labor markets. In: The Review of Economics and Statistics 75, 4, 753-761.

Berger, M. (2004): Les périurbains de Paris. De la ville dense à la métropole éclatée? Paris.

Berger, M.; Aragau, C.; Rougé, L. (2014): Vers une maturité des territoires périurbains? In: EchoGéo 27.

Bontje, M.; Burdack, J. (2011): Post-suburbia in Continental Europe. In: Phelps, N.A.; Wu, F. (eds.): International Perspectives on Suburbanization: A Post-Suburban World? Basingstoke, 143-163.

Brueckner, J.K. (2000): Urban sprawl: Diagnosis and remedies. In: International Regional Science Review 23, 2, 160-171.

Brueckner, J.K.; Thisse, J.-F.; Zenou, Y. (1999): Why is central Paris rich and downtown Detroit poor? An amenity-based theory. In: European Economic Review 43, 1, 91-107.

Burchfield, M.; Overman, H.G.; Puga, D.; Turner, M.A. (2006): Causes of Sprawl: A Portrait from Space. In: The Quarterly Journal of Economics 121, 2, 587-633. 
Burns, L.S. (1964): People or Jobs ... or Chickens and Eggs. In: Land Economics 40, 2, 231-234.

Cambon, G. (2016): La chaîne d'approvisionnement aéronautique et spatiale du grand Sud-Ouest. Poitiers. = Insee Analyses Aquitaine-Limousin-Poitou-Charentes 6.

Carlino, G.A.; Mills, E.S. (1987): The determinants of county growth. In: Journal of Regional Science 27, 1, 39-54.

Caruso, G. (2001): Peri-urbanisation: the situation in Europe. A bibliographical note and survey of studies in the Netherlands, Belgium, Great Britain, Germany, Italy and the Nordic countries. Report prepared for the DATAR, Délégation à l'Aménagement du Territoire et à l'Action Régionale. Ministère de l'Aménagement du Territoire et de l'Environnement, France. Louvain-la-Neuve.

Cavailhès, J.; Brossard, T.; Foltête, J.-C.; Hilal, M.; Joly, D.; Tourneux, F.-P.; Tritz, C.; Wavresky, P. (2009): GIS-based hedonic pricing of landscape. In: Environmental and Resource Economics 44, 4, 571-590.

Cavailhès, J.; Peeters, D.; Sekeris, E.; Thisse, J.-F. (2004): The Periurban City. Why to Live between the Suburbs and the Countryside? In: Regional Science and Urban Economics 34, 6, 681-703.

Chamberlin, E. (1933). The Theory of Monopolistic Competition. Cambridge, MA.

CGDD - Commissariat Général du Développement Durable (2013): Les comptes des transports en 2012. Premiers résultats. Paris.

Chen, Y.; Rosenthal, S.S. (2008): Local amenities and life-cycle migration: Do people move for jobs or fun? In: Journal of Urban Economics 64, 3, 519-537.

Cheshire, P.; Magrini, S. (2009): Urban growth drivers in a Europe of sticky people and implicit boundaries. Journal of Economic Geography $9,1,85-115$.

Coughlin, C.C.; Terza, J.V.; Arromdee, V. (1991): State characteristics and the location of foreign direct investment within the United States. In: The Review of Economics and Statistics 73, 4, 675683.

Crane, R.; Chatman, D.G. (2002): Traffic and sprawl: evidence from U.S. commuting, 1985 to 1997. Los Angeles.

Deding, M.; Filges, T.; van Ommeren, J. (2009): Spatial mobility and commuting: The case of two-earner households. In: Journal of Regional Science 49, 1, 113-147.

Decret, V.; Lupot, D.; Ballet, B. (2014). La filière aéronautique et spatiale en Aquitaine et Midi-Pyrénées, Edition 2013. Paris.

Draper, E.S., Sr. (1937): Where City and Country Meet (Typescript, additional draft, notes). Detroit, MI. = Earle Sumner Draper, Sr. Papers 2745/Box 1 (Division of Rare and Manuscript Collections, Cornell University Library).

Dumais, G.; Ellison, G.; Glaeser, E.L. (2002): Geographic concentration as a dynamic process. In: The Review of Economics and Statistics 84, 2, 193-204.

EEA - European Environment Agency (2006): Urban sprawl in Europe: The ignored challenge. Copenhagen. = EEA Report 10/2006.

Ellison, G.; Glaeser, E.L.; Kerr, W.R. (2010): What Causes Industry Agglomeration? Evidence from Coagglomeration Patterns. In: American Economic Review 100, 3, 1195-1213.

Floch, J.M. (2014): Des revenus élevés et en plus forte hausse dans les couronnes des grandes aires urbaines. In: INSEE - Institut National de la Statistique et des études économiques (ed.): France Portrait Social 2014. Paris, 69-81.

Fontes-Rousseau, C.; Jean, R. (2015): Utilisation du territoire. L'artificialisation des terres de 2006 à 2014: pour deux tiers sur des espaces agricoles. Montreuil-sous-bois. = Agreste Primeur 326.

Forkenbrock, D.J.; Foster, N.S.J. (1996): Highways and Business Location Decisions. In: Economic Development Quarterly 10, 3, 239-248.

Fujita, M.; Krugman, P.R.; Venables, A.J. (1999): The Spatial Economy: Cities, Regions and International Trade. Cambridge, MA.

Fujita, M.; Thisse, J.-F. (2002): Economics of Agglomeration: Cities, Industrial Location, and Regional Growth. Cambridge.
Gaigné, C.; Goffette-Nagot, F. (2008): Localisation rurale des activités industrielles. Que nous enseigne l'économie géographique? In: Revue d'Etudes en Agriculture et Environnement 87, 2, 101130.

Gibbons, S.; Lyytikäinen, T.; Overman, H.G.; Sanchis-Guarner, R. (2016). New Road Infrastructure: The Effects on Firms. London. $=$ CEPR Discussion Paper 11239.

Gilli, F. (2004): Choix de localisation des entreprises et périurbanisation des emplois. Dissertation, Université de Lille 1.

Glaeser, E.L.; Kahn, M.E. (2004): Sprawl and Urban Growth. In: Henderson, J.V.; Thisse, J.-F. (eds.): Handbook of Regional and Urban Economics. Volume 4: Cities and geography. Amsterdam, 24812527.

Glaeser, E.L.; Kerr, W.R. (2009): Local Industrial Conditions and Entrepreneurship: How Much of the Spatial Distribution Can We Explain? In: Journal of Economics and Management Strategy 18, 3, 623-663.

Gobillon, L.; Selod, H.; Zenou, Y. (2007): The Mechanisms of Spatial Mismatch. In: Urban Studies 44, 12, 2401-2427.

Gottlieb, P.D. (1994): Amenities as an economic development tool: Is there enough evidence? In: Economic Development Quarterly 8, $3,270-285$.

Gottlieb, P.D. (1995): Residential Amenities, Firm Location and Economic Development. In: Urban Studies 32, 9, 1413-1436.

Grossetti, M. (2001): Genèse de deux systèmes urbains d'innovation en France: Grenoble et Toulouse. In: Réalités Industrielles. Annales des Mines 2, 68-72

Guimarães, P.; Figueiredo, O.; Woodward, D. (2000): Agglomeration and the Location of Foreign Direct Investment in Portugal. In: Journal of Urban Economics 47, 1, 115-135.

Guimarães, P.; Rolfe, R.J.; Woodward, D. (1998): Regional incentives and industrial location in Puerto Rico. In: International Regional Science Review 21, 2, 119-138.

Halbert, L. (2007): From sectors to functions: producer services, metropolisation and agglomeration forces in the Ile-de-France region. In: BelGeo - Revue Belge de Géographie 1, 73-94.

Hesse, M.; Rodrigue, J.-P. (2004): The transport geography of logistics and freight distribution. In: Journal of Transport Geography 12, 3, 171-184.

Hilal, M.; Cavailhès, J.; Détang-Dessendre, C.; Legras, S.; Sencébé, Y. (2014): Accessibilité, sociabilité, centralité: trois regards sur la fragmentation sociale et spatiale de la ville. In: Ministère de l'Egalité des Territoires et du Logement; Ministère de l'Ecologie, du Développement durable et d'Energie; Plan Urbanisme Construction Architecture (eds.): Vivre en ville hors des villes. Synthèse du programme de recherche: La mobilité et le péri-urbain à l'impératif de la ville durable: ménager les territoires de vie des péri-urbains. La Defense, 21-28.

Hilal, M.; Schaeffer, Y.; Détang-Dessendre, C. (2013): Espaces ruraux et ruptures territoriales. In: Laurent, E. (ed.): Vers l'égalité des territoires. Dynamiques, mesures, politiques. La Documentation française. Paris, 62-77

Hogan, D.J.; Ojima, R. (2012): Urban Sprawl: A Challenge for Sustainability. In: Martine, G.; McGranahan, G.; Montgomery, M.; Fernandez-Castilla, R. (eds.): The new Global Frontier. Urbanization, Poverty and Environment in the 21st Century. London, 203216.

Holl, A. (2004a): Start-ups and relocations: manufacturing plant location in Portugal. In: Papers in Regional Science 83, 4, 649-668.

Holl, A. (2004b): Transport Infrastructure, Agglomeration Economies, and Firm Birth. Empirical Evidence from Portugal. In: Journal of Regional Science 44, 4, 693-712.

Holl, A. (2004c): Manufacturing location and impacts of road transport infrastructure: empirical evidence from Spain. In: Regional Science and Urban Economics 34, 3, 341-363.

Holl, A. (2012): Market potential and firm-level productivity in Spain. In: Journal of Economic Geography 12, 6, 1191-1215. 
Hoogstra, G.J.; Florax, R.J.G.M.; van Dijk, J. (2005): Do ‘jobs follow people' or 'people follow jobs'? A meta-analysis of Carlino-Mills studies. Paper for the 45th Congress of the European Regional Science Association 23-27 August 2005, Amsterdam.

Hotelling, H. (1929): Stability in Competition. In: The Economic Journal 39, 153, 41-57.

Hu, L. (2014): Changing Job Access of the Poor: Effects of Spatial and Socioeconomic Transformations in Chicago, 1990-2010. In: Urban Studies 51, 4, 675-692.

Huiban, J.-P. (2011): The spatial demography of new plants: Urban creation and rural survival. In: Small Business Economics 37, 1, 73-86.

Huiban, J.-P.; Aubert, F.; Dussol, A.-M. (2006): La démographie des établissements industriels: une différenciation entre espaces urbains, périurbains et ruraux. In: Revue d'Economie Régionale et Urbaine 5, 751-779.

INSEE - Institut National de la Statistique et des études économiques (2011): Zonages d'études. Méthode d'actualisation du nouveau zonage en aires urbaines 2010. Rapport méthodologique.

INSEE - Institut National de la Statistique et des études économiques (2015): Les zonages d'études de l'Insee. Une histoire des zonages supra communaux définis à des fins statistiques. Paris. $=\mathrm{IN}$ SEE methods 129. https://www.epsilon.insee.fr/jspui/bitstream/1/ 29553/1/imethode129.pdf (November 8, 2016).

Jofre-Monseny, J.; Marín-López, R.; Viladecans-Marsal, E. (2011): The Mechanisms of Agglomeration: Evidence from the Effect of Inter-Industry Relations on the Location of New Firms. In: Journal of Urban Economics 70, 2-3, 61-74.

Kain, J.F. (1968). Housing segregation, Negro employment, and metropolitan decentralization. In: The Quarterly Journal of Economics 82, 2, 175-197.

Kawamura, K. (2001). Empirical Examination of Relationship between Firm Location and Transportation Facilities. In: Transportation Research Record 1747, 97-103.

Kechidi, M.; Talbot, D. (2006): L'industrie aéronautique et spatiale: logique d'arsenal, logique commerciale. In: Colletis, G.; Lung Y. (eds.): La France industrielle en question. Analyses sectorielles. Paris, 73-86.

Knapp, T.A.; Gravest, P.E. (1989): On the role of amenities in models of migration and regional development. In: Journal of Regional Science 29, 1, 71-87.

Kohler, H.-P. (1997): The Effect of Hedonic Migration Decisions and Region-Specific Amenities on Industrial Location: Could Silicon Valley Be in South Dakota? In: Journal of Regional Science 37, 3, 379-394.

Kronenberg, K. (2013): Firm relocations in the Netherlands: Why do firms move, and where do they go? In: Papers in Regional Science $92,4,691-713$

Krugman, P.R. (1991a): Increasing Returns and Economic Geography. In: Journal of Political Economy 99, 3, 483-499.

Krugman, P.R. (1991b): Geography and Trade. Leuven.

Krugman, P.R. (1993): First Nature, Second Nature, and Metropolitan Location. In: Journal of Regional Science 33, 2, 129-144.

Krumme, G. (1968): Werner Sombart and the economic base concept. In: Land Economics 44, 1, 112-116.

Lainé, F. (2000): Périurbanisation des activités économiques et mouvement d'emploi des établissements. In: Pumain, D.; Mattei, M.-F. (eds.): Données urbaines 3. Paris, 251-260.

Lamure, C. (1992): La ville et l'automobile. In: Culture technique 25, 175-183.

Le Jeannic, T. (1997): Trente ans de périurbanisation: extension et dilution des villes. In: Economie et Statistique 307, 1, 21-41.

Leduc, S.; Wilson, D.J. (2012): Should Transportation Spending be included in a Stimulus Program? A Review of the Literature. San Francisco. $=$ Federal Reserve Bank of San Francisco Working Paper 2012-15.

Lösch, A. (1940): The Economics of Location. Yale.
Lowry, I.S. (1966): Migration and metropolitan growth: two analytical models. San Francisco.

Marigot, S. (2003): Des salariés apparemment mieux payés en MidiPyrénées. Toulouse. $=$ Insee Midi-Pyrénées Publications 67.

Marshall, A. (1920): Principles of Economics. London.

Mills, E.S. (1967): An aggregative model of resource allocation in a metropolitan area. In: The American Economic Review 57, 2, 197-210.

Muth, R.F. (1969): Cities and housing. Chicago.

Nechyba, T.J.; Walsh, R.P. (2004): Urban Sprawl. In: Journal of Economic Perspectives 18, 4, 177-200.

Newman, P.W.; Kenworthy, J.R. (1989): Cities and Automobile Dependence. A Sourcebook. Aldershot.

Nilsson, K.; Pauleit, S.; Bell, S.; Aalbers, C.; Sick Nielsen, T.A. (eds.) (2013): Peri-urban futures: Scenarios and models for land use change in Europe. Berlin/Heidelberg.

Partridge, M.D. (2010): The duelling models: NEG vs amenity migration in explaining US engines of growth. In: Papers in Regional Science 89, 3, 513-536.

Paulus, F. (2004): Coévolution dans les systèmes de villes: croissance et spécialisation des aires urbaines françaises de 1950 à 2000. Paris.

Phelps, N.A.; Wu, F. (eds.) (2011): International Perspectives on Suburbanization: A Post-Suburban World? Basingstoke.

Pollard, J. (2009): Political Framing in National Housing Systems: Lessons from Real Estate Developers in France and Spain. In: Schwartz, H.; Seabrooke, L. (eds.): The Politics of Housing Booms and Busts. Basingstoke, 170-188.

Redding, S.J.; Turner, M.A. (2015): Transportation costs and the spatial organization of economic activity. In: Duranton, G.; Henderson, J.V.; Strange, W.C. (eds.): Handbook of Regional and Urban Economics. Volume 5: Economics. Amsterdam, 1339-1398.

Rosenthal, S.S.; Strange, W.C. (2001): The Determinants of Agglomeration. In: Journal of Urban Economics 50, 2, 191-229.

Rosenthal, S.S.; Strange, W.C. (2008): The attenuation of human capital spillovers. In: Journal of Urban Economics 64, 2, 373-389.

Schönfeld, T.; Jouaillec, F. (2008): The regional Aerospace Cluster Policy in Europe. 26th International Congress of the Aeronautical Sciences. Anchorage, Alaska, USA.

Sivitanidou, R.; Sivitanides, P. (1995): Industrial Rent Differentials: The Case of Los Angeles. In: Environment and Planning A 27, 7, 1133-1146.

Smith, D.F.; Florida, R. (1994): Agglomeration and Industrial Location: An Econometric Analysis of Japanese-Affiliated Manufacturing Establishments in Automotive-Related Industries. In: Journal of Urban Economics 36, 1, 23-41.

Timothy, D.; Wheaton, W.C. (2001): Intra-Urban Wage Variation, Employment Location, and Commuting Times. In: Journal of Urban Economics 50, 2, 338-366.

Venables, A.J. (1996): Equilibrium Locations of Vertically Linked Industries. In: International Economic Review 37, 2, 341-359.

Vickerman, R.W. (1980): Spatial economic behavior. Basingstoke.

Wasylenko, M. (1980): Evidence of Fiscal Differentials and Intrametropolitan Firm Relocation. In: Land Economics 56, 3, 339-349.

Weber, A. (1909): Über den Standort der Industrien. Tübingen.

Weitz, J.; Crawford, T. (2012): Where the Jobs Are Going: Job Sprawl in U.S. Metropolitan Regions, 2001-2006. In: Journal of the American Planning Association 78, 1, 53-69.

Whyte, W.H. Jr. (1958): Urban Sprawl. In: Whyte, W.H. Jr. (ed.): The Exploding Metropolis. New York, 114-139.

Zenou, Y. (2004): Les inégalités dans la ville. In: Maurel, F.; Perrot, A.; Prager, J.-C.; Thisse, J.-F. (eds.): Villes et Economie. Paris, 109128. 